\title{
The Future Is Now
}

\author{
MITCH McCONNELL
}

A $T$ THE CONCLUSION of the debate on campaign finance reform in both 2001 and 2002 , I took to the floor of the United States Senate to map out for my colleagues what this law would do if enacted: decimate the national parties, crown the stealth outside group king of a soft money monarchy and stifle political discourse at a time when it is most importantimmediately preceding an election. Colleagues from both sides of the aisle honored me with their presence those days and I recall their reactions ranging from shock to pure disbelief. It was my hope that the Constitution would be at its strongest when we in Congress were not. However, the Supreme Court has decided not to save Congress from itself and we now live under the very system I described, decried and fought against for nearly a decade.

On December $10^{\text {th }}, 2003$, the Supreme Court issued a decision that secured a new world order in politics. In one fell swoop and by a margin of only one vote, the Supreme Court bestowed upon Congress extraordinary authority to regulate speech. Gone is unfettered discussion of issues in the month or two before an election. Gone is a political party's ability to compete with outside special interest groups. Gone is the ability of federal officeholders to fully engage in state politics. In a Shermanesque manner, the Supreme Court marched through my best efforts to regain the liberties stripped by Congress. Section by section, the Supreme Court repeatedly tipped the scale toward alleged Congressional wisdom in the balancing act of regulating political speech. How-

Mitch McConnell is a Republican Senator from the State of Kentucky and was lead plaintiff in McConnell v. Federal Election Commission, 124 S. Ct. 619 (2003). ever, Justice Kennedy aptly observes in his dissent that "[o]ur precedents teach, above all, that Government cannot be trusted to moderate its own rules for suppression of speech."1

The Supreme Court majority adopted not only the reform industry's rationales, but more surprisingly, their rhetoric. The majority opinion repeatedly referred to funds raised by a national party to support state and local candidates and activities as a "soft-money loophole." Ending "so-called" or "sham" issue advocacy was found to be within the discretion of the Congress. Further, much was made of provisions justified as "valid anticircumvention measures" - such as restrictions on state and local parties and candidates. The court has spoken, albeit in a manner reminiscent of hundreds of New York Times editorials, and we must move on.

This new world order under the Bipartisan Campaign Reform Act of 2002 (BCRA) was developing while the courts considered the case. Reform groups and editorial pages are owning up to the fact that not one dime has been removed from the political process. In fact, in a stunning pronouncement in a David Broder column in the Washington Post, he quoted reformer Thomas Mann, who worked closely with the law's sponsors, as saying that they "were not intending to reduce the amount of money in politics. Politics costs a lot of money."2 In a sharply divided series of opinions, concurrences and dissents totaling nearly 300 pages, even the Court's majority agrees

\footnotetext{
${ }^{1}$ McConnell, 124 S. Ct. at 743 (Kennedy, J., dissenting in part).

${ }^{2}$ David S. Broder, Campaign Finance Casualties, WAsH.
} Post, Dec. 17, 2003, at A43. 
that "[m]oney, like water, will always find an outlet." 3

The soft money of today, call it "super-sized soft" as it's larger and more plentiful than the original, will be spent by outside groups only and will be even stronger than before. National party soft money of yesteryear was fully disclosed and its usage was governed in large measure by the laws of the 50 states. Many of the new groups won't disclose a single dime to the public and most are not regulated by state laws. The question of whether the new law will put an end to the campaign finance scandals of yesteryear is worth asking. The answer is possibly yes but not for the reason one might think-without public disclosure there will be no public scandals.

Billionaires like George Soros are pooling tens of millions of soft dollars with unions and special interest groups to create new unregulated political groups. With seemingly innocuous sounding names like "Americans Coming Together," these new groups will spend upwards of half a billion dollars to run attack ads, register voters and get their voters to the polls. Again, unlike the parties which had to disclose their soft dollars, the public will never know the source of the funds for many of these new groups.

The discussion has begun about whether these new organizations will be considered "political committees" and thus subject to regulation by FECA, BCRA and the Federal Election Commission (FEC). The FEC has examined this issue in the past and will examine it again. Whether the vehicle is a 527, a 501(c) or another type of entity, trying to squeeze money out of politics is like putting a rock on Jell-O. This is just the tip of the iceberg as creative lawyers, many of whom represent the party which in large part brought you BCRA, examine the law and the Supreme Court opinion for options and avenues to guide future action. Make no mistake, money will ebb and flow, but the national and state party system has been fundamentally changed forever, barring a shift in the court or Congress.

The reform industry has argued, and surprisingly 5 members of the court agreed, that the parties, raising only hard dollars from individuals up to $\$ 25,000$ per year, will be able to compete with organizations that raise all soft money unlimited in amount or source. Accepting that proposition means the local ACE hardware store can compete with Home Depot and the local bait shop can battle Wal-Mart. One needs only to look at the numbers for the party committees to see the fallacy of this proposition. Less than one year out from the 2004 elections, at least one party committee is still in the red and the others are operating with at least 50\% less income than in years past. The other 50\% now resides with unregulated outside special interest groups. Based on predictions in the media, the total net fundraising dollars of all six national committees will be less that $20 \%$ of that of the outside groups. That percentage is most definitely high as it doesn't account for the massive unregulated and largely unreported ground game waged by labor unions.

The new regime reigns supreme not only at the national level, but at the state and local level as well. Any time a federal candidate or officeholder is involved, they bring with them their "coat of many regulations." This coat is long, thick and can be stretched a country mile, making room under it for any candidate who dare approach. This vast web of restrictions through which any elected official must weave carries with it potential criminal penalties for missteps. During one speech on this issue, I noted that BCRA really stands for "before campaigning, retain attorney." Sadly this is what it has become and it applies not only to candidates for U.S. Congress and the Presidency, but also County Commissioner and City Council. Wherever we go, and whatever we do, the FEC and the Department of Justice are waiting in the wings to spring into action.

The new restrictions kick in with full force and effect whenever there is a federal candidate on the ballot. Last Congress we passed historic legislation to fundamentally alter the way elections are conducted. 4 To support our efforts, we appropriated $\$ 3$ billion dollars in FY '03 and '04 to assist states and localities in upgrading their systems to root out fraud and ensure legally eligible voters are able to vote, but only once. One of the unintended consequences

\footnotetext{
${ }^{3}$ McConnell, 124 S. Ct. 706.

${ }^{4}$ Help America Vote Act of 2002, Public Law 107-252(Oct. 29, 2002).
} 
of BCRA, and there are many, may be to force states to move their state and local elections to odd numbered years. This is the only way candidates for mayor or the state house can avoid federal intervention. It may be a few years in the making, but I believe BCRA not only totally overhauls how elections are conducted, but also when they are conducted.

Another provision upheld by the Supreme Court is the restriction on issue advocacy 30 days before a primary and 60 days before a general election. We now live in a world in which greater protections are afforded to virtual child pornography and dissemination of illegally intercepted communications than to criticisms of elected officials. This speech steamroller fired up its engine for the first time on December $28^{\text {th }}$ for the January $27^{\text {th }}$ New Hampshire primary. Taking a look at the 2004 calendar, the impact of the issue ad restriction on the general election is quite stunning. For the Republican party, due to the date of its convention, the 60day period is actually a 90 -day period, with issue advocacy being restricted beginning July $29^{\text {th }}$ and ending on election day, November $2^{\text {nd }}$.

In addressing this issue, the Supreme Court gave the Heisman to Buckley v. Valeo, ${ }^{5}$ calling it "functionally meaningless" as it relates to issue advocacy. Apparently the dearth of "studies" and "submissions" which the reformers proffered swayed 5 members of the Court that organizations advocating issues are really advocating candidates. Actually, the record is replete with complaints from Members of Congress that negative advertisements were an albatross of their campaigns. Now, in the waning days of an election, the new hard money world protects lawmakers from unfettered criticism of their voting records.

Finally, no writing on this subject can be complete without a tip of the hat to the media for their fine work ensuring the blanket exemption they secured over the many years of debate. Not only did the reform industry exempt the press, but they protected them as well from political parties, political committees or candidates which may own or control such facilities. Over the past 5 years, over 300 editorials on campaign finance have been published at an average rate of at least one per week in the New York Times, Washington Post and USA
Today. This organizational obsession used corporate money to argue that the very same money for national political parties was the root of all evil. They did not have a problem with the use of soft money, so long as they were the ones using it. According to Justice Kennedy, this law is "the codification of an assumption that the mainstream media alone can protect freedom of speech." 6

The First Amendment to the Constitution provides, in the very same clause, that "Congress shall make no law ... abridging the freedom of speech, or of the press." Query whether the reformers will agree with Justice Thomas in his dissent, that the freedom of the press "could be the next on the chopping block."7 As Justice Thomas further points out in his conclusion, "[t]he press now operates at the whim of Congress." 8 But perhaps the reformers will abide by old adage that you don't bite the hand that feeds you.

With their stunning victory in the Supreme Court, one might think the outrage lobby, a.k.a. the reform industry, would be placated. Unfortunately, they have just been emboldened. The panacea for reformers is taxpayer financing for all elections and they are taking steps in that direction. The reformers dropped three reform lines into the pond last Congress: reduced rate media time, overhaul of the presidential financing system and abolition of the Federal Election Commission as currently constituted. Each idea is worse than the next and hopefully any Members of Congress who didn't vote their convictions last time around will now realize they are shooting with real bullets and this Supreme Court isn't a Kevlar vest.

Address reprint requests to: Office of the Majority Whip S-208, The Capitol Washington, DC 20510

E-mail: Brian_Lewis@mcconnell.senate.gov

\footnotetext{
${ }^{5} 424$ U.S. 1 (1976).

${ }^{6}$ McConnell, 124 S. Ct. at 743 (Kennedy, J., dissenting in part).

${ }^{7}$ Id. at 742 (Thomas, J., dissenting in part).

${ }^{8}$ Id.
} 